\title{
Modelling diatom life forms and ecological guilds for river biomonitoring
}

\author{
Rémy Marcel $^{1, *}$, Vincent Berthon ${ }^{1}$, Virginie Castets ${ }^{1}$, Frédéric Rimet ${ }^{2}$, Amélie Thiers ${ }^{1}$, \\ Frédéric Labat ${ }^{1}$ and Bruno Fontan ${ }^{1}$ \\ ${ }^{1}$ Aquabio, 10 rue Hector Guimard, 63800 Cournon d'Auvergne, France \\ 2 INRA, UMR CARRTEL, 75 av. de Corzent, BP511 - 74230 Thonon les Bains, France
}

\begin{abstract}
Biomonitoring is central to the European Union's Water Framework Directive (WFD) and to the French water and aquatic environmental law, but most diatom indices do not separate different anthropogenic impacts. To address this gap, the effect of water chemistry on diatom ecological guilds and life forms was assessed in order to indicate stream perturbations. Generalised additive models (GAMs) were built on a large-scale data set of 1571 samples from the French monitoring network. The relationships between diatom ecological guild and life form metrics were investigated by Principal components analysis and the results predicted by GAMs. The models characterised eight chemical parameters that modified adaptive strategies (ecological guilds) and growth morphology (life forms). Total phosphorus, conductivity, nitrate and $\mathrm{pH}$ are the main influencing factors, followed by temperature, dissolved oxygen and organic matter. The findings confirm three groups of diatoms with different adaptive strategies: 1 - fast moving species, 2 - species growing close to the substrate and 3 - species extending to the surface layers of the biofilm. Thirteen diatom metrics displayed a variety of responses to different ranges of the eight chemical parameters. These metrics could be used to help to identify and quantify which chemical alterations are caused by polluted effluents in rivers.
\end{abstract}

Keywords: benthic diatoms / ecological guilds / biological traits / biomonitoring / generalised additive model

Résumé - Modélisation des formes de vie et guildes écologiques des diatomées pour la bioindication en rivières. La bioindication est centrale dans la directive cadre européenne sur l'eau et la loi française sur l'eau, mais la plupart des indices diatomiques ne séparent pas les différents impacts anthropiques. Pour combler ce manque, l'effet de la physico-chimie de l'eau sur les guildes écologiques et formes de vies des diatomées a été étudié pour indiquer des perturbations des cours d'eau. Des modèles additifs généralisés (GAMs) ont été construits sur un jeu de données de 1571 échantillons des réseaux de suivi des cours d'eau français. Les relations entre les métriques de guildes écologiques et formes de vie des diatomées ont été étudiées par une ACP et les résultats prédits par des GAMs. Les modèles ont caractérisé huit paramètres physico-chimiques qui modifient les stratégies adaptatives (guildes écologiques) et morphologies de croissance (formes de vie). Le phosphore total, la conductivité, les nitrates et le $\mathrm{pH}$ sont les facteurs les plus influents, suivis par la température, l'oxygène dissous et la matière organique. Les résultats confirment trois groupes de diatomées avec des stratégies adaptatives différentes : 1 - les espèces se déplaçant rapidement, 2 - les espèces proches du substrat et 3 - les espèces s'étendant vers la surface du biofilm. Quatorze métriques diatomiques ont montré une variété de réponses à différentes gammes de valeurs des huit paramètres physico-chimiques. Ces métriques pourraient être utilisées pour aider à identifier et quantifier quelles altérations chimiques sont causées par les rejets polluants dans les rivières.

Mots clés : diatomées benthiques / guildes écologiques / traits biologiques / bioindication / modèle additif généralisé

\footnotetext{
* Corresponding author: remy.marcel@aquabio-conseil.fr
} 


\section{Introduction}

Numerous anthropogenic impacts, such as industrialisation, intensive agriculture and urbanisation are causing chemical and hydro-morphological alterations to aquatic environments (Allan, 2004; Bader and Baccini, 1993). These impairments affect biofilm functions, such as primary production, trophic interactions, stabilisation of sediments, and regulation of nutrient cycling (Poulíčková et al., 2008) and can be monitored by using the indicator value of microalgae. Studying the mechanisms linking biofilms to their environment provides an opportunity to better understand the impact of human activities on freshwater ecosystems and implement more appropriate protective and restorative programs. Biomonitoring is an essential part of environmental impact assessment because it provides a diagnosis of aquatic ecosystems based on the characteristics of their biota. It assesses not only chemical concentrations, but also effective human impacts on the biosphere, because organisms and communities respond distinctly to different chemical and physical changes, integrating multiple alterations on both spatial and temporal scales (Rimet, 2012; Reyjol et al., 2013; Stevenson, 2014). In Europe, biomonitoring has developed quickly as a result of the WFD (2000), which requires the evaluation of the quality status of water bodies based on their chemical and biological statuses. The WFD asks every member state to develop bioindicators for each Biological Quality Element: phytoplankton; macrophytes and phytobenthos; macroalgae and angiosperms; benthic invertebrates; and fish. While the WFD focuses on large-scale ecological status definition, the French water and aquatic environments law (LEMA, 2006) defines a number of human activities as subject to environmental impact assessment, requiring finer investigation of anthropogenic mechanisms of disruption.

The great majority of European diatom indices that are routinely used for river quality assessment are based on specific pollution sensitivity (Rimet, 2012), and on the formula of Zelinka and Marvan (1961). In France, diatom bioindication tools were standardised more than ten years ago (AFNOR, 2003, 2004, 2007), the two main indices being the Diatom Biological Index (DBI, Coste et al., 2009) and the Specific Polluosensitivity Index (SPI, CEMAGREF, 1982). They are designed to assess both nutrient and organic matter levels in rivers (Lange-Bertalot, 1979), but they cannot discriminate between these sources of pollution. Neither were these indices designed to detect any other type of water impairment (e.g., deoxygenation, acidification, water warming or alteration of conductivity).

Data collected concerning life forms and ecological guilds can provide useful information about benthic diatoms and biofilms. An ecological guild is a group of taxa co-existing in the same environment and exploiting the same resources, which can display different adaptations to abiotic factors (DeVito et al., 2004; Fauth et al., 1996). The ecological guilds of Passy (2007) were developed based on diatoms nutrients preferenda and their resistance to water turbulence. A classification of diatoms into different life forms was proposed by Rimet and Bouchez (2012). Life forms are morphological traits describing the shapes that diatoms adopt when growing. The life forms are adaptations to habitat selection, nutrient capture, sinking rate, attachment and light in periphytic biofilms (Round et al., 1990). In situ studies (B-Béres et al.,
2014; Stenger-Kovács et al., 2013) carried out on freshwater biofilms concluded that diatom life forms and ecological guild metrics are useful in detecting nutrient and organic matter enrichment, or pesticide contamination (Rimet and Bouchez, 2011). Several large-scale studies have been carried out using monitoring network data, which have also highlighted the potential of these diatom metrics as bioindicators (Berthon et al., 2011; Marcel et al., 2013).

The objective of this study is to assess whether metrics based on diatom ecological guilds and life forms could be used to assess the impact of chemical and physical water alterations in the French river monitoring network. Increasing nutrient and organic matter contamination can modify the relative abundances of ecological guilds and life forms, as observed by Berthon et al. (2011) in the Rhône river basin. Several authors reported a reduction in the abundance of the low-profile (LPG) and high profile guilds (HPG) and colonial life form as well as an increased abundance of the motile guild (MG) in contaminated sites (B-Béres et al., 2014; Berthon etal., 2011; Hlúbiková et al., 2014). Acidic conditions can be favourable to either the high profile (Gottschalk and Kahlert, 2012) or the low profile (Pound et al., 2013) guild. At low conductivities the high profile guild is expected to increase, while motile diatoms are expected to decrease (Stenger-Kovács et al., 2013). This study proposes the hypothesis that sites contaminated by inorganic phosphorus should have lower abundances of low-profile, high-profile, pad, stalk, arbuscular and all types of colonial diatoms and higher abundances of motile, mobile, adnate and non-colonial diatoms. Inorganic nitrogen, organic matter, conductivity, temperature, $\mathrm{pH}$ and dissolved oxygen (DO) are expected to have different effects on diatom ecological guilds and life forms. The hypothesis was tested on a large scale data set encompassing several hundred French river basins, which were monitored for their ecological quality using diatom samples, and chemical and physical measurements.

\section{Materials and methods}

\subsection{Study area}

Samples were taken from three major hydrographical basins in France (Fig. 1), the Loire, the Rhône and the Garonne catchments. Human population density varies in the studied areas. There are highly populated, cultivated and industrialised plains and mountain ranges less impacted by human activity. The Loire basin is mainly impacted by agricultural activities, with $65 \%$ of the catchment occupied by agricultural land, with mainly cattle, crops and pig farming. The main industries are meat processing, milk and canning industries. This basin also has five power stations and seventeen hydroelectric dams. Other less important pressures on rivers include chemical, textile and paper industries and viticulture. The Loire basin has a population of 12.7 million inhabitants and a density ranging from 40 to 200 inhabitants $/ \mathrm{km}^{2}$, with an average of 75 inhabitants $/ \mathrm{km}^{2}$. It has four cities of 500000 inhabitants, one city of one million inhabitants and five littoral touristic areas. The regions of the Rhône basins incorporated in this study include 1-an area dominated by forest land, cattle and milk, automobile and rail industries. This area has 1.2 million inhabitants and one major city with 250000 inhabitants. 2-A highly populated area (2 million inhabitants, 110 inhabitants $/ \mathrm{km}^{2}$ ) 

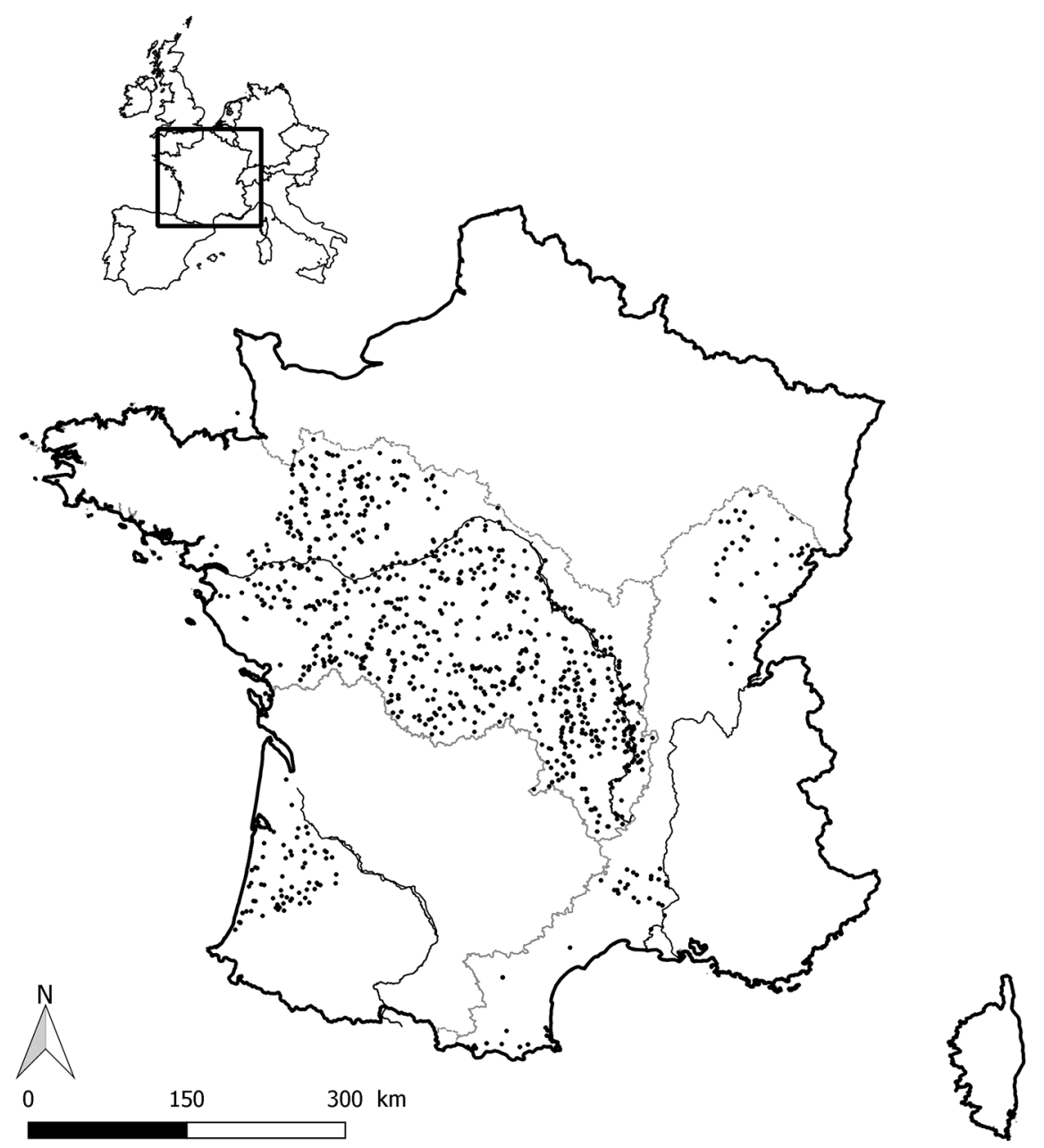

Fig. 1. Study area. The 1571 sampling sites are displayed as dots. The three major rivers are displayed as black lines and their hydrographical basins are delimited by grey lines. Major rivers: Loire (west), Rhône (south-east) and Garonne (south-west).

dominated by viticulture and tourism, with two cities of 300000 inhabitants and one city of 500000 inhabitants. The area of the Garonne basin incorporated in this study has low population (350000 inhabitants, 40 inhabitants $/ \mathrm{km}^{2}$ ), with one major city of 70000 inhabitants and is dominated by forest land and the touristic and poultry industries.

According to the WFD standards, the ecological statuses of the water bodies found within the data set are as follows: 71 "bad" sites, 193 "poor", 789 "moderate", 384 "good" and 134 "high". The study area covers a wide range of river sizes, with Strahler ranks from 1 to 8 . There are also multiple geologies, including granitic, basaltic and calcareous subsoils and different topographies, with high mountains, highlands and sandy plains. The area encompasses various climatic zones (Wasson et al., 2002).

\subsection{Diatom sampling and analysis}

Fieldwork was performed between 2009 and 2014 by Aquabio as part of the national biomonitoring program for rivers. The sampling sites were not chosen to assess any specific anthropogenic pressure, they were placed to be representative and integrate all the pressures of their reaches. The sampling procedure followed the French standard (AFNOR, 2007). In the French WFD monitoring program, diatoms are collected once a year, during the low-flow period (June to September) to minimize the influence of spates and correspond to the higher pollutants concentrations. Benthic diatoms were collected from at least five stones, from macrophytes or from artificial substrates found in the lotic parts of the sampling sites. The upper surfaces of the substrates were scrubbed with a toothbrush to collect the biofilm formed by diatoms. The samples were fixed in $90 \%$ ethanol or $4 \%$ formaldehyde. In the laboratory, the diatom valves were cleaned using $40 \% \mathrm{H}_{2} \mathrm{O}_{2}$ and $\mathrm{HCl}$. Clean valves were mounted in resin (Naphrax(C). At least 400 valves from each sample were counted and identified using a light microscope $(1000 \times$ magnification) according to European (CEN, 2003) and French (AFNOR, 2007) standards. The abundances of all observed taxa were expressed as relative counts. Identifications were carried out to species and sub-species level using Krammer and Lange-Bertalot (1986, 1988, 1991a and b) and Hofmann et al. (2011) floras and additional taxonomical bibliography (e.g., Lange-Bertalot, 1993, 2001; Lange-Bertalot and Krammer, 2002, 2003; Levkov, 2009; Reichardt, 1999).

\subsection{Chemical and physical analyses}

Chemical and physical analyses were carried-out at the diatom sampling sites every month. DO, conductivity (Cond), 
temperature $(\mathrm{T})$ and $\mathrm{pH}$ were measured in the field. For dissolved organic carbon (DOC), nitrite $\left(\mathrm{NO}_{2}{ }^{-}\right)$, ammonium $\left(\mathrm{NH}_{4}{ }^{+}\right)$, nitrate $\left(\mathrm{NO}_{3}{ }^{-}\right)$, phosphate $\left(\mathrm{PO}_{4}{ }^{3-}\right)$, total phosphorus (TP) and five-day biological oxygen demand (BOD5), water samples were collected and analysed according to standard procedures (APHA, 2012) by a laboratory on behalf of the regional Water Agencies.

\subsection{Database construction}

Two kinds of data were combined for each site: 1-diatom abundances; 2-chemical and physical measurements. The species counts were provided by Aquabio and were used to calculate the relative abundance of each ecological guild and life form. As the data came from species counts on cleaned samples, the ecological guilds and life forms were not observed in the samples but assigned to species posteriorly, according to the literature (Round et al., 1990; Passy, 2007; Rimet and Bouchez, 2012). The chemical and physical data were provided by the Adour-Garonne, Loire-Bretagne and Rhône-Méditerranée Water Agencies. The averages of the chemical measurements were calculated based on the results of the ninety days preceding each diatom sampling date.

\subsection{Diatom metrics}

Metrics based on two classifications were tested, one representing growth morphology (life forms) and a second one based on adaptive strategies (ecological guilds).

\subsubsection{Life forms}

Life forms express the diversity of attachment, mobility and type of colonies with regards to the different diatom growth forms. The life forms of the few taxa that were not described by Rimet and Bouchez (2012) were completed according to Round et al. (1990). All the diatoms were grouped into eleven life forms (Rimet and Bouchez, 2012):

- Adnate: cells attached to the substrate by the whole valve area (e.g., Amphora spp., Cocconeis spp.).

- Pedunculate: cells secreting a mucilaginous peduncle from their apex. "Pedunculate" are divided into:

- Pad: cells producing a short peduncle (e.g., Ulnaria spp.).

- Stalk: cells producing a long peduncle, forming a stalk (e.g., Achnanthidium spp., Gomphonema spp.).

- Non-colonial: solitary cells.

- Colonial: the different types of colonies can be classified as:

- Filamentous colonies: centric cells juxtaposed by their valves (e.g., Melosira spp.) or by granules (e.g., Melosira varians).

- Ribbon colonies: pennate cells juxtaposed by their valves (e.g., Staurosira venter).

- Arbuscular colonies: cells secreting mucilaginous stalks and forming ramifications diverging from each cell (e.g., Rhoicosphenia abbreviata).

- Mucous tube colonies: files of cells forming a mucilaginous tubule inside which they can move (e.g., Encyonema spp.).

- Mobile: taxa having the ability to move by means of their raphe system. The mobile life form differs from the motile ecological guild: Taxa of the mobile life form are capable or either slow or fast movement, unlike taxa of the MG, which are adapted to move rapidly.

\subsubsection{Ecological guilds}

Ecological guilds reflect the different strategies developed by diatoms to adapt to abiotic factors. They are based on the ability of the species to use nutrient resources and tolerate physical disturbance. The three tested ecological guilds are based on the ones modified from Passy (2007) and described by Rimet and Bouchez (2012). The three ecological guilds were distinguished as follows:

- Low-profile: species growing in nutrient-poor waters and tolerating physical disturbances, such as those caused by currents. This group is formed by small species, species directly attached to the substrate by the whole valve area, species attached parallel to the substrate by the apex or attached perpendicularly and slow-moving species. Genera such as Achnanthes, Achnanthidium, Amphora, Cocconeis, Cymbella, Opephora and Remeria pertain to this group.

- High-profile: species growing in polluted waters (nutrient and organic matter-rich) but sensitive to physical disturbance: longer erect species, filamentous, "branched" (arborescent), pedunculate and chain or tube-forming species. Genera such as Diatoma, Eunotia, Fragilaria, Gomphoneis, Gomphonema and Ulnaria pertain to this group. The ability to form colonies enables this guild to extend to the surface of the biofilm and exploit resources unavailable to the "low-profile" guild, but makes it more vulnerable to current turbulence and grazing.

- Motile: species proliferating in nutrient-rich waters, capable of fast motion and continuously migrating to find suitable growth conditions. Genera such as Navicula, Nitzschia, Sellaphora and Surirella pertain to this group. Passy (2007) showed that these taxa are not resistant to physical disturbances.

\subsection{Selection of metrics and descriptors and statistical analyses}

The statistical method relies on generalised additive models (GAMs) (Hastie and Tibshirani, 1990) to build a quantitative multimetric diagnostic method. The interest of these models is to allow the prediction of a value for an environmental parameter based on diatom metrics, without presuming a probability distribution and taking into account the non-linearity of the relationships between variables.

Principal components analysis (PCA) of diatom abundance data after Hellinger transformation (Legendre and Gallagher, 2001) was used to summarise the metric distributions. The first five principal components (PC) were kept and identified as explaining significant proportions of the variance in the metrics data under the broken-stick distribution (Jackson, 1993). Thereafter, GAMs were used (Hastie and Tibshirani, 1990) to separate and quantify the influence of chemical and physical parameters on the distribution of the metrics. For each PC of the PCA, a GAM was built with the metrics scores on the $\mathrm{PC}$ considered as the response variable and the chemical and physical parameters as the predictors. PCA and GAM operations were performed on R2.11.0 statistical software 
Table 1. Summary of the data set $(n=1571)$ for the eight tested chemical and physical parameters: conductivity $(\mathrm{Cond})$, $\mathrm{pH}$, temperature $(\mathrm{T})$, dissolved oxygen (DO), total phosphorus (TP), nitrate $\left(\mathrm{NO}_{3}{ }^{-}\right.$), dissolved organic carbon (DOC), five-day biological oxygen demand (BOD5).

\begin{tabular}{lllll}
\hline Parameter & Mean $(95 \%$ confidence interval) & Median & Minimum & Maximum \\
\hline Cond $\left(\mu \mathrm{S} \mathrm{cm}^{-1}\right)$ & $388(12)$ & 360 & 22 & 2364 \\
$\mathrm{pH}$ & $7.7(0.02)$ & 7.7 & 5.8 & 9.6 \\
$\mathrm{~T}\left({ }^{\circ} \mathrm{C}\right)$ & $15.7(0.14)$ & 15.6 & 5.0 & 26.9 \\
$\mathrm{DO}\left(\mathrm{mg} \mathrm{L}^{-1}\right)$ & $9.077(0.072)$ & 9.200 & 1.600 & 15.320 \\
$\mathrm{TP}\left(\mathrm{mg} \mathrm{L}^{-1}\right)$ & $0.132(0.008)$ & 0.090 & 0.005 & 3.525 \\
$\mathrm{NO}_{3}^{-}\left(\mathrm{mg} \mathrm{L}^{-1}\right)$ & $13.474(0.630)$ & 8.733 & 0.100 & 88.800 \\
$\mathrm{DOC}\left(\mathrm{mg} \mathrm{L}^{-1}\right)$ & $5.165(0.170)$ & 4.567 & 0.500 & 39.333 \\
BOD5 $\left(\mathrm{mg} \mathrm{L}^{-1}\right)$ & $1.882(0.060)$ & 1.733 & 0.500 & 14.500 \\
\hline
\end{tabular}

(R Development Core Team, 2013) using the vegan v2.0-8 package (Oksanen et al., 2015) and the mgcv v1.7-24 package (Wood, 2008, 2011), respectively.

In the first step, PCA, GAMs and automated model selection by "dredge" (Wood and Wood, 2015) were used to select the most efficient diatom metrics and chemical and physical descriptors. Thirteen metrics were selected as adding substantial information and there were eight statistically significant descriptors. In a second step, PCA, GAMs and automated model selection by "dredge" were used with the selected metrics and descriptors to model the biofilm responses. In the PCA of this second step, for each PC, the diatom metrics having a loading which absolute value is superior to 0.4 were considered as conclusive and compared to the GAM results. In each GAM with scores on one PC as response variable, the contribution $-\mathrm{s}()-$ to the model and the standard error of the contribution - se.s () - were extracted for all 1571 samples. For a given descriptor, a sample is considered as non-significant if its contribution is not statistically significantly different from the intercept, namely if $|\operatorname{se} . s()|>|s()|$.

\section{Results}

A total of 1424 taxa from 1571 samples are recorded in the data set. Diatoms were sampled form natural hard substrates (stones, gravels, pebbles or rocks) in $97.5 \%$ of the sites, from macrophytes in $1.5 \%$ of the sites and from artificial substrates in $1 \%$ of the sites. On average, the dominant ecological guild was the low profile guild $(44.6 \%)$, followed by the motile $(39.6 \%)$ and high profile $(11.7 \%)$ guilds. The mean relative abundances of the life forms were distributed as follows: noncolonial (87.8\%), mobile (86.8\%), adnate (25.4\%), stalk (23.8\%), colonial (12.0\%), pad (5.7\%), ribbon colony $(4.4 \%)$, arbuscular colony $(4.2 \%)$, filamentous colony $(1.8 \%)$ and mucous tubule colony (1.0\%).

The mean values, $95 \%$ confidence intervals and the median, minimum and maximum values of the eight selected chemical and physical parameters are shown in Table 1 .

The plots of the life forms and ecological guilds along the environmental gradients are presented in Appendices 1 and 2. Table 2 presents the characteristics of the five axes of the PCA, the parameters of the GAMs predicting each PCA axis and the statistics and ranking of the significant descriptors of each GAM.

\subsection{PCA results}

Eighty-three percent of the variance is explained by the first five axes of the PCA on the diatom metrics data (Tab. 2). In Figure 2 the first axis (PC1) reveals an opposition between the sessile diatoms from the upper layers of the biofilm (Colonial, Ribbon, HPG, Pad) and the vagile ones (Mobile), the former having negative loadings and the latter having positive ones. PC2 shows an opposition between vagile diatoms (MG) and diatoms from the lower layers of the biofilm (LPG), the former having negative loadings and the latter having positive ones. PC3 corresponds to the diatoms forming arbuscular colonies, PC4 to an opposition between the lower (Adnate) and upper (Stalk) layers of the biofilm and PC5 to the diatoms forming mucous tubes and filamentous colonies.

\subsection{GAMs results}

Figure 3 presents the results of the each of the five GAMs, predicting the scores of each of the respective axis of the PCA (PC1 to PC5).

\subsubsection{GAM on the first axis (PC1)}

The results of Figures 2 and 3 are complementary and permit to deduce the range of values of each chemical and physical parameter which is favourable or disfavourable to each diatom ecological guild or life form. This chapter details how the results were deduced for the parameters and diatom metrics of the first axis of the PCA, while Tables 3-5 give the results for all the axis of the PCA.

In Figure 3, for PC1, s(TP) denotes the contribution of the samples to the model, with regard to their TP concentrations. Samples with positive s(TP) contribute to the prediction of positive scores on PC1 (Fig. 2). Therefore, the higher the s(TP) (Fig. 3), the more the samples TP concentrations contribute to the prediction of high relative abundances of the life forms and guilds with positive loadings on PC1 (Mobile and Non-colonial, Fig. 2). Alongside this observation, in Figure 3, samples with positive $\mathrm{s}(\mathrm{TP})$ have the highest TP concentrations (0.095 to $\left.0.753 \mathrm{mg} \mathrm{L}^{-1}\right)$. It is thus possible to conclude that Mobile and Non-colonial diatoms are favoured by high TP levels. Figure 3 shows that the Mobile and Non-colonial metrics are also favoured by higher Cond (216 to $782 \mu \mathrm{S} \mathrm{cm}^{-1}$ ), $\mathrm{NO}_{3}{ }^{-}$ (8.0 to $50 \mathrm{mg} \mathrm{L}^{-1}$ ) and $\mathrm{pH}(7.7$ to 13.1$)$. 
Table 2. Summary of the GAMs fitted to the diatom principal component (PC) scores. Descriptors significantly explaining variance are presented in descending order of their contribution to the GAMs and represented as follows: * $p$-value $<0.05$; ***p-value $<0.001$. DESCRIPTORS: total phosphorus (TP), conductivity (Cond), nitrate $\left(\mathrm{NO}_{3}{ }^{-}\right)$, $\mathrm{pH}$, temperature (T), dissolved oxygen (DO), dissolved organic carbon (DOC), five-day biological oxygen demand (BOD5). COLUMN LABELS: proportion of variance (\%; variance explained by the PCA axis), deviance explained (\%; deviance is a measure of residual variation around the GAMs analogous to the sum of squares in linear regression), AICC (Akaike Information Criterion), LogLik (log-likelihood), df (degrees of freedom).

\begin{tabular}{|c|c|c|c|c|c|c|}
\hline PCA axes & Proportion of variance & Deviance explained & $\mathrm{AICC}$ & LogLik & df & Descriptors \\
\hline PC1 & 31.4 & 24.2 & 6403 & -3174 & 27.3 & $\begin{array}{l}\mathrm{TP}^{* * *} \\
\mathrm{Cond}^{* * *} \\
\mathrm{NO}_{3}^{-* * * *} \\
\mathrm{pH}^{* * *}\end{array}$ \\
\hline $\mathrm{PC} 2$ & 24.6 & 27.1 & 5972 & -2952 & 32.7 & $\begin{array}{l}\mathrm{TP}^{* * *} \\
\text { Cond*** } \\
\mathrm{T}^{* * *} \\
\mathrm{pH}^{* * *} \\
\mathrm{DO}^{* * *}\end{array}$ \\
\hline PC3 & 11.1 & 29.2 & 4655 & -2303 & 23.6 & $\begin{array}{l}\mathrm{TP}^{* * *} \\
\mathrm{pH}^{* * *} \\
\mathrm{~T}^{* *} \\
\mathrm{DOC}^{* *}\end{array}$ \\
\hline PC4 & 9.8 & 17.9 & 4702 & -2326 & 24.6 & $\begin{array}{l}\mathrm{NO}_{3}^{-* * *} \\
\mathrm{~T}^{* * *} \\
\mathrm{BOD}^{* *}\end{array}$ \\
\hline PC5 & 6.2 & 11.4 & 4111 & -2023 & 31.9 & $\begin{array}{l}\text { Cond } * * * \\
\mathrm{TP}^{* * *} \\
\mathrm{pH}^{* * *} \\
\mathrm{DOC}^{* * *} \\
\text { BOD5*** }\end{array}$ \\
\hline
\end{tabular}

The Colonial, Ribbon, HPG and Pad diatoms have negative loadings on PC1 (Fig. 2), and their relative abundances are therefore higher in samples with negative s(TP) (namely, negative contributions to the model). Figure 3 shows that the samples with negative $\mathrm{s}(\mathrm{TP}), \mathrm{s}(\mathrm{Cond}), \mathrm{s}\left(\mathrm{NO}_{3}{ }^{-}\right)$and $\mathrm{s}(\mathrm{pH})$ correspond to the lowest values of TP $\left(0.005\right.$ to $\left.0.083 \mathrm{mg} \mathrm{L}^{-1}\right)$, Cond (22 to $\left.185 \mu \mathrm{S} \mathrm{cm}^{-1}\right), \mathrm{NO}_{3}^{-}\left(0.1\right.$ to $\left.6.6 \mathrm{mg} \mathrm{L}^{-1}\right)$ and $\mathrm{pH}$ (5.8 to 7.7$)$, respectively.

\section{Discussion}

The present study is based on a higher number of samples and higher catchment area than other comparable studies (BBéres et al., 2014; Berthon et al., 2011; Hlúbiková et al., 2014; Marcel et al., 2013; Stenger-Kovács et al., 2013). Berthon et al. (2011) defined six diatom metrics as indicators for two parameters (saprobity and trophic status) in one river basin. This study increases the number of metrics to thirteen and the number of environmental parameters to eight. It also covers a wider area, with three river basins including all the French diatom-ecoregions (Tison et al., 2007). It permitted as well to highlight the relationships between different chemical and physical parameters and diatom metrics. Tables 3-5 show that the chemical and physical parameters structuring the diatom ecological guilds and life forms are, in order of decreasing importance: TP, Cond, $\mathrm{NO}_{3}{ }^{-}, \mathrm{pH}, \mathrm{T}, \mathrm{DO}, \mathrm{DOC}$ and BOD5. GAMs appear to be a powerful method for use in environmental studies, as illustrated by Alric et al. (2013),
Berthon et al. (2014) and Zarauz et al. (2008). But the prediction of precise values for environmental parameters was not possible, because factors such as light, grazing, current velocity, spates, depth, geology, substrate, humic substances or metals were not taken into account. However this study shows a predictable behaviour of diatom ecological guilds and life forms and the models were able to sort the studied parameters that have the strongest effects, identify those having non-linear correlations with the diatom metrics and establish ranges of responses for each parameter (Tabs. 4 and 5). Those ranges represent response thresholds between which the diatom metrics respond and are predicted by the GAM. It also means that outside these ranges, any further modification of the water properties towards extreme values no longer modified the biofilm structure and the metrics. Therefore, the tested diatom metrics and GAMs could bring quantitative information to environmental managers in a diagnostic method.

The results of this study can be applied to compare sites with the same geology and morphology, particularly for environmental impact assessment of wastewater treatment plants and sewage, industrial or agricultural effluents in a river. These impact assessments are designed to exclude the impact of any other factor than the studied perturbation. The sampling sites are located upstream and downstream of the perturbation and are distant enough to allow water mixing, but not excessively distant to avoid any change in river type, geology of morphology. In such cases the diatom communities are impacted by chemical changes and the results of the present study can be applied. The analysis of diatom ecological guilds 

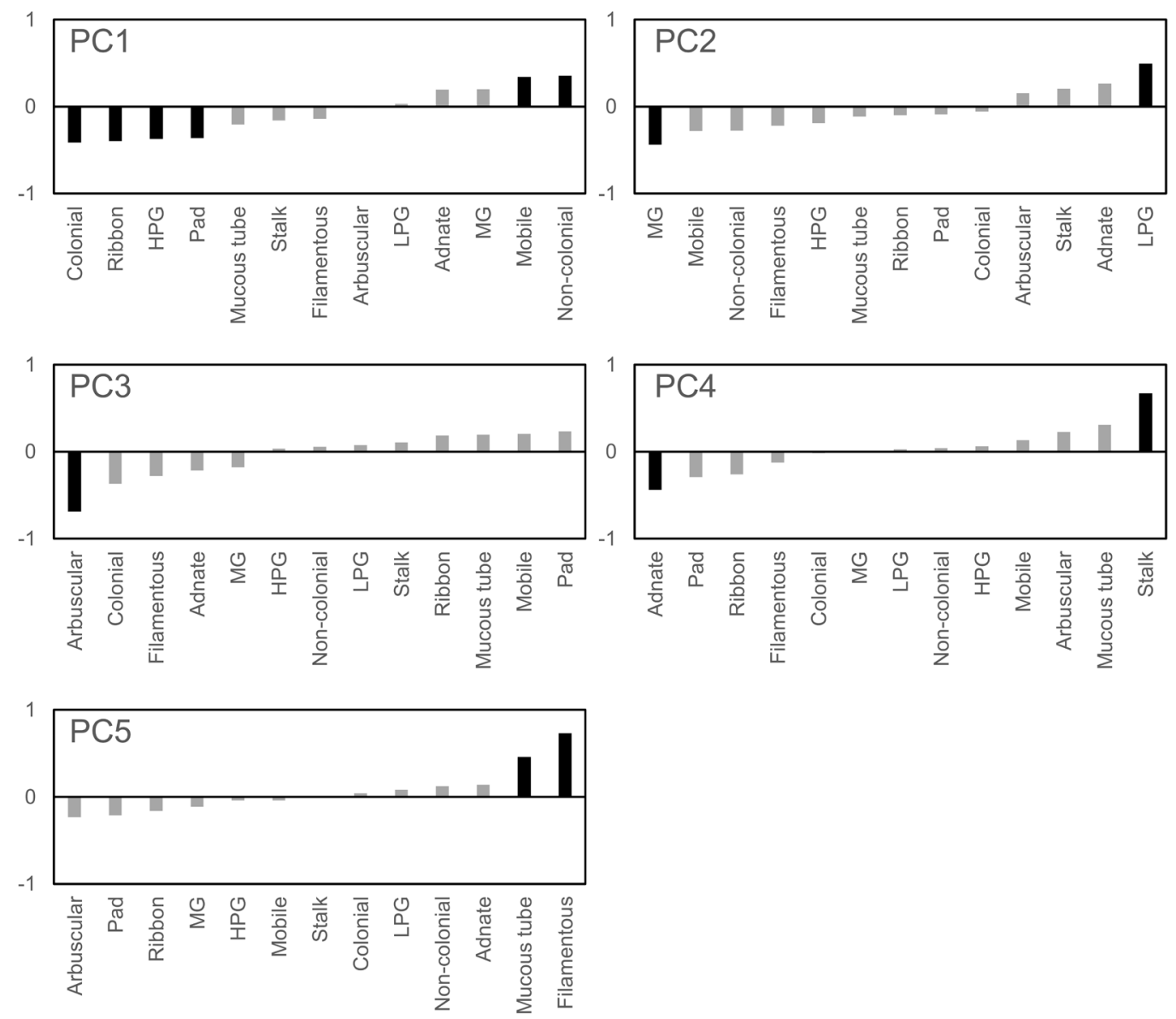

Fig. 2. Metric loadings on the five axes (PC1 to PC5) of the PCA. The black bars represent metrics whose loadings are considered to be conclusive for their PC. The three ecological guilds are named as follows: HPG: high profile guild; LPG: low profile guild; MG: motile guild.

and life forms is complementary of the use of other diagnostic methods, indices or chemical analysis. The DBI or SPI can provide information about the general state of the diatom community and a study of the ecological guilds and life forms can make diagnosis more specific by identifying if a disruption of $\mathrm{TP}$, conductivity, nitrate, $\mathrm{pH}$, temperature, $\mathrm{DO}$ or organic matters is implicated. The ecological guilds and life forms permit to determine if the implicated parameter values are increasing or decreasing and to estimate in which range of values each parameter is increasing or decreasing. For instance, a significant increase in the abundance of the colonial, ribbon colonies, high profile and pad diatoms indicates an increased TP (Tab. 3) and suggests that TP varies between 0.005 and $0.083 \mathrm{mg} \mathrm{L}^{-1}$ (Tab. 4). Besides, a chemical and physical analysis can detect an alteration of TP, conductivity, nitrate, $\mathrm{pH}$, temperature, $\mathrm{DO}$ or organic matters at a given time, and a study of the diatom ecological guilds and life forms can confirm or reject if this alteration has been durable over the course of the ninety proceeding days.

The diatom metrics that are most abundant at low TP levels correspond to small, fast-growing diatoms (low profile; Tab. 3) that can rapidly develop on bare substrates in nutrient-poor environments (Hoagland et al., 1982; Sabater, 2000; Rimet et al., 2009). They are followed by filamentous algae and colonial, mucous tubule, filamentous, ribbon colonies, high profile and pad diatoms, which also appear to prefer phosphorus-poor streams. These latter life forms grow in the upper layer of the biofilm to avoid the decreasing nutrient gradient of the biofilm and to access nutrients from the water column and light (Steinman et al., 1989). Arburscular colonies, motile, mobile and non-colonial diatoms thrive at high phosphorus concentrations. They share the characteristic of synthesising extracellular enzymes that give them the ability to consume macromolecules (Pringle, 1990). Species forming arbuscular colonies store the enzymes in their stalk, which plays the role of a nutrient pump (Ellwood and Whitton, 2007). It has also been observed that motile diatoms are on average larger than low profile species and their elongated shape gives them a higher surface/volume ratio and thus more ion and nutrient uptake sites (Egge, 1998). They are also capable of rapid displacement and are adapted to their environment by having the ability to migrate within the biofilm from resource-depleted to richer areas (Johnson et al., 1997).

Nitrate has a similar effect to TP on selection between vagile diatoms (mobile) and sessile diatoms from the surface layers of the biofilm (colonial, high profile, pad and ribbon colonies; Tab. 3). However, $\mathrm{NO}_{3}{ }^{-}$did not show the impact found for TP on 1 - the dichotomy between vagile diatoms and diatoms growing close to the substrate and $2-$ the relative abundances of arbuscular, filamentous and mucous tubule colonies. Similarly, inorganic nitrogen plays a role in the opposition between adnate and stalked diatoms, whereas TP does not. The adnate life form encompasses the mobile and most of the low-profile diatoms. They are fast-growing species which could be favoured at high levels of nitrate because of 

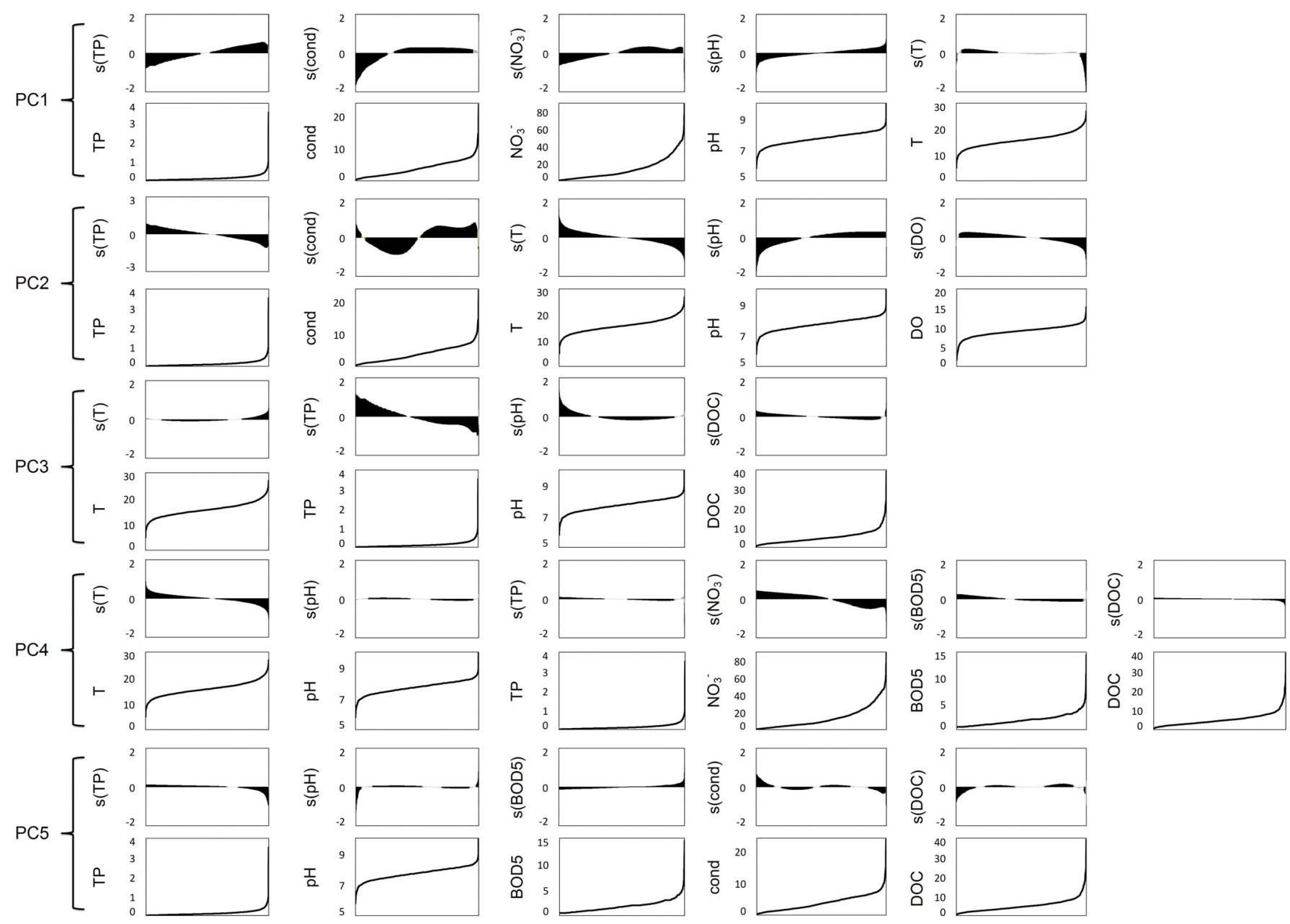

Fig. 3. GAMs results. All graphs have in the x-axis the 1571 samples, in ascending order of their values for the involved descriptor. For each PCA axis (PC1 to PC5), the upper lines of the graphs present in the $y$-axis the contribution $-\mathrm{s}()$ - of the descriptors used in the GAM with scores on this PC as response variable. The grey zones represent non-significant samples (i.e. not statistically significantly different from the intercept) and the black zones represent significant samples. Descriptors are presented in descending order (from left to right) of their contribution to the GAMs. For each PC, the lower lines of the graphs present in the y-axis the values taken by the corresponding descriptor (lower graph units: TP in $\mathrm{mg} \mathrm{L}^{-1}$; $\mathrm{T}$ in ${ }^{\circ} \mathrm{C}$; $\mathrm{NO}_{3}{ }^{-}$in $\mathrm{mg} \mathrm{L}^{-1}$; cond in $\mathrm{mS} \mathrm{cm}{ }^{-1}$; BOD5 in $\mathrm{mg} \mathrm{L}^{-1}$; $\mathrm{DO}$ in $\mathrm{mg} \mathrm{L}^{-1}$; DOC in $\mathrm{mg} \mathrm{L}^{-1}$ ). DESCRIPTORS: total phosphorus (TP), conductivity (cond), nitrate $\left(\mathrm{NO}_{3}{ }^{-}\right), \mathrm{pH}$, temperature (T), dissolved oxygen (DO), dissolved organic carbon (DOC), five-day biological oxygen demand (BOD5).

nutrient stimulation but are less competitive in dense mature biofilms (Stevenson et al., 1991). Stalked diatoms appear to have an advantage when $\mathrm{NO}_{3}{ }^{-}$levels are low, meanwhile adnate diatoms could profit from decreased competition from stalked diatoms when $\mathrm{NO}_{3}{ }^{-}$levels are high.

Conductivity appears to influence the differences in abundance between sessile diatoms from the surface layers (colonial, ribbon, high profile, pad), which are more abundant at low electrolyte content, and vagile diatoms (motile) that favour high conductivities (Tab. 3). The selection between vagile (motile, being more abundant at intermediate electrolyte contents) and "low-rise" metrics (low profile, being more abundant at low electrolyte contents) also seems to be driven by conductivity. Low conductivity values are generally naturally occurring, whereas higher conductivities can be either natural or due to human impact. These results are consistent with the Stenger-Kovács et al.'s (2013) study, which reports low abundances of the high profile guild at high conductivities and an increase of motile diatoms at high chloride levels. Among the different ions, chloride is an important parameter, as it can inhibit photosynthesis (Dionisio-Sese and Miyachi, 1992) and growth (Videau et al., 1980) in a number of diatoms.

Acidic $\mathrm{pH}$ was associated with higher abundances of vagile diatoms (motile) and sessile diatoms from the surface layers (colonial, ribbon, high profile, pad; Tab. 3). Neutral $\mathrm{pH}$ favoured arbuscular, filamentous and mucous tubule colonies, while alkaline $\mathrm{pH}$ increased the abundance of "low-rise" diatoms (non-colonial, mobile and low profile). The growth and competitive abilities of diatoms are influenced by $\mathrm{pH}$ through its control over nutrient availability, metal solubility and enzymatic activity (Battarbee et al., 2001). This was illustrated in our results by a decrease in the arbuscular diatoms. The stalks of the latter contain phosphatase (Ellwood and Whitton, 2007), the activity of which is controlled by $\mathrm{pH}$. The dominance of highprofile, more edible, diatoms in acidic conditions could be a result of a top-down effect caused by decreased grazing pressure 
Table 3. Summary table of the GAM results, showing the influence of the chemical and physical parameters on diatom metrics. The relationships were coded as follows: "+" positive relationship; “-" negative relationship; "mid" metric favoured by medium-range values of the parameter. The metrics were ordered according to the absolute values of their loading on the PCA axes. Chemical and physical parameters are presented in descending order of their contribution to the GAM. PARAMETERS: total phosphorus (TP), conductivity $(\mathrm{Cond})$, nitrate $\left(\mathrm{NO}_{3}{ }^{-}\right)$, $\mathrm{pH}$, temperature (T), dissolved oxygen (DO), dissolved organic carbon (DOC), five-day biological oxygen demand (BOD5).

\begin{tabular}{|c|c|c|c|c|c|c|c|c|c|}
\hline PCA axes & Diatom metrics & $\mathrm{TP}$ & Cond & $\mathrm{NO}_{3}{ }^{-}$ & $\mathrm{pH}$ & $\mathrm{T}$ & DO & DOC & BOD5 \\
\hline \multirow[t]{6}{*}{$\mathrm{PC} 1$} & Colonial & - & - & - & - & & & & \\
\hline & Ribbon & - & - & - & - & & & & \\
\hline & High profile & - & - & - & - & & & & \\
\hline & $\mathrm{Pad}$ & - & - & - & - & & & & \\
\hline & Non-colonial & + & + & + & + & & & & \\
\hline & Mobile & + & + & + & + & & & & \\
\hline \multirow[t]{2}{*}{$\mathrm{PC} 2$} & Low profile & - & + & & + & - & - & & \\
\hline & Motile & + & $\operatorname{mid}$ & & - & + & + & & \\
\hline PC3 & Arbuscular & + & & & + & - & & + & \\
\hline \multirow[t]{2}{*}{ PC4 } & Stalk & & & - & & - & & & - \\
\hline & Adnate & & & + & & + & & & + \\
\hline \multirow[t]{2}{*}{ PC5 } & Filament & - & & & mid & & & + & + \\
\hline & Mucous tubule & - & & & mid & & & + & + \\
\hline
\end{tabular}

Table 4. Ranges of $\mathrm{TP}$, Cond, $\mathrm{NO}_{3}{ }^{-}$and $\mathrm{pH}$ to which diatom metrics respond. The relationships were coded as follows: " $\nearrow$ " range of the parameter having a positive effect on the diatom metrics; "\" range of the parameter having a negative effect on the diatom metrics. The metrics were ordered according to the absolute values of their loading on the PCA axes. Chemical and physical parameters are presented in descending order of their contribution to the GAM. PARAMETERS: total phosphorus (TP), conductivity (Cond), nitrate $\left(\mathrm{NO}_{3}{ }^{-}\right), \mathrm{pH}$.

\begin{tabular}{|c|c|c|c|c|c|c|}
\hline $\begin{array}{l}\text { PCA } \\
\text { axes }\end{array}$ & \multicolumn{2}{|c|}{ Diatom metrics } & $\begin{array}{c}\mathrm{TP} \\
\left(\mathrm{mg} \mathrm{L}^{-1}\right)\end{array}$ & $\begin{array}{c}\text { Cond } \\
\left(\mu \mathrm{S} \mathrm{cm}^{-1}\right)\end{array}$ & $\begin{array}{c}\mathrm{NO}_{3}^{-} \\
\left(\mathrm{mg} \mathrm{L}^{-1}\right)\end{array}$ & $\mathrm{pH}$ \\
\hline \multirow{4}{*}{ PC1 } & \multirow{2}{*}{$\begin{array}{l}\text { Colonial } \\
\text { Ribbon } \\
\text { High profile } \\
\text { Pad }\end{array}$} & $\pi$ & $0.005-0.083$ & $22-185$ & $0.1-6.6$ & $5.8-7.7$ \\
\hline & & $\mathbf{y}$ & $0.095-0.753$ & $216-782$ & $8.0-50$ & $7.7-13.1$ \\
\hline & \multirow{2}{*}{$\begin{array}{l}\text { Non-colonial } \\
\text { Mobile }\end{array}$} & $\pi$ & $0.095-0.753$ & $216-782$ & $8.0-50$ & $7.7-13.1$ \\
\hline & & $\mathbf{y}$ & $0.005-0.083$ & $22-185$ & $0.1-6.6$ & $5.8-7.7$ \\
\hline \multirow{4}{*}{$\mathrm{PC} 2$} & \multirow[t]{2}{*}{ Low profile } & $\lambda$ & $0.005-0.091$ & $\begin{array}{c}22-75 \\
380-1052\end{array}$ & & $7.7-8.8$ \\
\hline & & $\mathbf{y}$ & $0.100-0.940$ & $100-360$ & & $5.8-7.6$ \\
\hline & \multirow[b]{2}{*}{ Motile } & $\pi$ & $0.100-0.940$ & $100-360$ & & $5.8-7.6$ \\
\hline & & $\mathbf{y}$ & $0.005-0.091$ & $\begin{array}{c}22-75 \\
380-1052 \\
\end{array}$ & & $7.7-8.8$ \\
\hline \multirow{2}{*}{ PC3 } & \multirow{2}{*}{ Arbuscular } & $\pi$ & $0.083-0.790$ & & & $7.5-8.2$ \\
\hline & & y & $0.005-0.077$ & & & $5.8-7.4$ \\
\hline \multirow{4}{*}{ PC4 } & \multirow{2}{*}{ Stalk } & $\pi$ & & & $0.1-10.2$ & \\
\hline & & y & & & $11.8-88$ & \\
\hline & \multirow{2}{*}{ Adnate } & $\pi$ & & & $11.8-88$ & \\
\hline & & $\mathbf{y}$ & & & $0.1-10.2$ & \\
\hline \multirow{2}{*}{ PC5 } & \multirow{2}{*}{\multicolumn{2}{|c|}{$\begin{array}{l}\text { Filament } \\
\text { Mucous tubule }\end{array}$}} & $0.005-0.127$ & & & $7.3-7.8$ \\
\hline & & & $0.161-1.375$ & & & $\begin{array}{l}5.8-7.0 \\
8.0-9.6 \\
\end{array}$ \\
\hline
\end{tabular}

Table 5. Ranges of T, DO, DOC and BOD5 to which diatom metrics respond. The relationships were coded as follows: " $\nearrow$ " range of the parameter having a positive effect on the diatom metrics; "\" range of the parameter having a negative effect on the diatom metrics. The metrics were ordered according to the absolute values of their loading on the PCA axes. Chemical and physical parameters are presented in descending order of their contribution to the GAM. PARAMETERS: temperature $(T)$, dissolved oxygen (DO), dissolved organic carbon (DOC), five-day biological oxygen demand (BOD5).

\begin{tabular}{|c|c|c|c|c|c|c|}
\hline $\begin{array}{l}\text { PCA } \\
\text { axes }\end{array}$ & \multicolumn{2}{|c|}{ Diatom metrics } & $\begin{array}{c}\mathrm{T} \\
\left({ }^{\circ} \mathrm{C}\right)\end{array}$ & $\begin{array}{c}\mathrm{DO} \\
\left(\mathrm{mg} \mathrm{L}^{-1}\right)\end{array}$ & $\begin{array}{c}\text { DOC } \\
\left(\mathrm{mg} \mathrm{L}^{-1}\right)\end{array}$ & $\begin{array}{l}\text { BOD5 } \\
\left(\mathrm{mg} \mathrm{L}^{-1}\right)\end{array}$ \\
\hline \multirow{4}{*}{ PC2 } & \multirow{2}{*}{ Low profile } & $\lambda$ & $5.0-15.7$ & $5.6-9.3$ & & \\
\hline & & y & $15.8-26.9$ & $9.6-15.3$ & & \\
\hline & \multirow{2}{*}{ Motile } & $\lambda$ & $15.8-26.9$ & $9.6-15.3$ & & \\
\hline & & y & $5.0-15.7$ & $5.6-9.3$ & & \\
\hline \multirow{2}{*}{$\mathrm{PC} 3$} & \multirow{2}{*}{ Arbuscular } & $\pi$ & $12.9-16.6$ & & $4.3-11.2$ & \\
\hline & & y & $17.7-26.9$ & & $0.5-3.7$ & \\
\hline \multirow{4}{*}{ PC4 } & \multirow{2}{*}{ Stalk } & $\lambda$ & $5.0-15.7$ & & & $0.5-1.3$ \\
\hline & & y & $16.0-26.9$ & & & $1.6-4.7$ \\
\hline & \multirow{2}{*}{ Adnate } & $\pi$ & $16.0-26.9$ & & & $1.6-4.7$ \\
\hline & & $y$ & $5.0-15.7$ & & & $0.5-1.3$ \\
\hline \multirow{3}{*}{ PC5 } & \multirow{3}{*}{$\begin{array}{l}\text { Filament } \\
\text { Mucous tubule }\end{array}$} & $\pi$ & & & $\begin{array}{l}2.7-4.2 \\
5.8-8.6\end{array}$ & $1.9-14.5$ \\
\hline & & & & & & \\
\hline & & $y$ & & & $\begin{array}{c}0.3-2.3 \\
15.9-20.5\end{array}$ & $0.5-1.9$ \\
\hline
\end{tabular}


from acid sensitive macroinvertebrates (crustaceans, molluscs, leaches and insects) (Planas, 1996). Conductivity and $\mathrm{pH}$ vary according to different geological substrates but are also modified by numerous human impacts. These parameters are probably inter-correlated in this study, with similar effect on ecological guilds and life forms. Planas (1996) reports an increased competition by bacteria at $\mathrm{pH}$ close to seven, with a decreased nutrient availability for diatoms. The results of the present study confirm this hypothesis and show higher abundances of upper storey diatoms (colonial, high profile, pad, and ribbon, arbuscular, filamentous and mucous tubule colonies), which are able to avoid the competition by bacteria in the biofilm and access nutrients from the water column. Similarly, motile diatoms are also more abundant at $\mathrm{pH}$ close to seven, due to their fast motion and continuous migration to find suitable growth conditions and avoid the competition by bacteria. On the contrary low-rise slow moving diatoms (low profile, noncolonial and mobile) are put at a disadvantage by the competition by bacteria at $\mathrm{pH}$ close to seven.

The metrics found in cold waters correspond to diatoms from both the lower (low profile) and the upper layers (arbuscular and stalk), whereas higher temperatures favoured adnate and fast moving (motile) diatoms (Tab. 3). These high temperatures can coincide with down-stream larger rivers, lower flow speeds, anthropic impacts and warm effluents rich in nutrients and organic matter. Our results show that the MG has a positive response to both temperature and $\mathrm{TP}$ and that the adnate life form is favoured by warm water with high $\mathrm{NO}_{3}{ }^{-}$ and BOD5 values. Regarding stalked and arbuscular life forms, which grow in the upper layers on the biofilm, their decrease at higher temperatures could be due to increased activity of predators and increased grazing pressures found in warm waters (Steinman, 1996).

BOD5 and DOC are parameters that evaluate the organic matter content of waters. Although they appear to have a lower impact on biofilm architecture than nutrients and conductivity, five ecological guilds and life forms (filamentous, mucous tubule, adnate, arbuscular and stalked) were significantly affected by organic matter (Tab. 3). It has a positive effect on filamentous and mucous tubule colonies, adnates and arbuscular diatoms and a negative effect on stalked diatoms. These disparities might be linked to the different degrees of tolerance of diatoms to organic matter, with regards to their ability to withstand anoxia and switch between autotrophic and heterotrophic metabolism (Van Dam et al., 1994). Van Dam et al. (1994) defined nitrogen-autotrophic taxa which only tolerate low concentrations of organically bound nitrogen. The GAM results are corroborated by the observation that nitrogenautotrophic taxa represent the majority $(70 \%)$ of the stalked life form. The resistance of filamentous colonies, adnate and arbuscular diatoms to higher levels of organic matter is coherent with Van Dam et al. (1994) and also with Larras et al. (2012), who report a higher resistance of these metrics to organic matter and herbicides. However, the abundance of mucous tubule colonies increased with BOD5 and DOC in our study, while most of them are classified as nitrogenautotrophic by Van Dam et al. (1994).

Although competition processes are present inside a guild at the species level (McCormick, 1996), Passy and Larson (2011) proposed a succession model of "neutral coexistence" and observed that the diatom guilds neither suppress, nor facilitate each other. At the ecological guild level, adaptation to the environment appears to be a stronger driving factor for diatom communities than competition (Larson and Passy, 2012). We can therefore think that the responses of our metrics are not related to inter-guild competition but are due to environmental changes. Several environmental parameters are known to impact ecological guilds and life forms. For instance, high light exposure causes the formation of complex biofilms with multiple layers and enhances the competitive advantage of the MG in nutrient consumption (Lange et al., 2011). Diatom communities also change with geology and river typology (Rimet, 2009; Tison et al., 2005), current velocity (Steinman and McIntire, 1986), predation (Feminella and Hawkins, 1995; Steinman, 1996), depth (Cantonati et al., 2009), type of substrate (Cazaubon et al., 1995; Eminson and Moss, 1980; Torrisi et al., 2006), hydrology (Falasco et al., 2016) and according to the presence of humic substances or metals (Morin et al., 2008). The high profile guild, by virtue of its position in contact with the water column, is probably the ecological guild under the influence of the greatest number of factors, including light (Lange et al., 2011), current intensity (Passy, 2007; Stenger-Kovács et al., 2013), predation (Steinman, 1996) and exposure to herbicides (Larras et al., 2014; Marcel et al., 2013; Rimet and Bouchez, 2011).

In this study, higher abundances of the high profile guild were found at low nutrient levels, confirming the findings of Hlúbiková et al. (2014) in a land use study, Rimet et al. (2009) in a site study, and Rimet and Bouchez (2011) in mesocosms. The low profile and MGs displayed relationships with nutrients and organic matter similar to those found by B-Béres et al. (2014), Passy (2007) and Stenger-Kovács et al. (2013). These authors show a decrease of the LPG and an increase of the MG when nutrient and organic matter contaminations increase. However, they also report that the high profile guild is favoured by nutrient enrichment, which was not the case in this study. The results of the present study corroborate the findings of Berthon et al. (2011) for the three ecological guilds and the colonial and stalk life forms, the only difference being that a positive impact of organic matter on the mucous tubule colonies was determined in the present study.

\section{Conclusions}

This study demonstrates the structuring effect of chemical and physical conditions of streams on periphytic biofilms. Consequently, human activities impairing water physicochemistry also alter the microalgae community framework. The parameter with the greatest effect is TP, followed by conductivity, nitrate and $\mathrm{pH}$. Organic matter enrichment also modified biofilms structure, but to a lesser extent than the abovementioned parameters. The ecological guilds and life forms selected by water physico-chemistry are the ones corresponding to the three ecological guilds of Passy (2007), thus confirming the important adaptive strategies adopted by different diatoms: 1-continuously moving species, 2 -species growing close to the substrate and 3-species growing in the upper layers.

The GAMs allowed the establishment of a list of thirteen diatom metrics and found a variety of responses to eight chemical and physical parameters. The results showed that not all responses were linear, and that some of them display response 
thresholds. This shows that diatom life forms and ecological guilds could be successful metrics for a water contamination diagnostic method. Berthon et al. (2011) showed that each metric can be as efficient as traditional indices (DBI and SPI) at indicating trophic and organic matter levels. A diagnostic method combining our eight diatom metrics would make the most of the ecological guild and life form classifications, and by itself allow the identification of different types of water contamination and the deduction of ranges of values for environmental parameters.

Impaired steams are often under multiple stresses (European Commission, 2003) and diatom metrics such as life-forms and ecological guilds are known to be strongly correlated with nutrient and organic matter concentrations (e.g., Passy, 2007; Berthon et al., 2011) but also with parameters that were not assessed in this study, such as river size and geology (e.g., Biggs and Gerbeaux, 1993; Cattaneo et al., 1997; Passy, 2007; Song, 2007). An approach based on ecological guilds and life forms is suitable to disentangle the interactions of multiple stressors and understand how nutrients, water flow and substrates shape diatom communities (Lange et al., 2015). The results of this study could help industrials and environmental managers to identify and quantify which specific chemical and physical alterations are caused by a polluted effluent in a river. Future research should focus on reference sites with low human impact and include measures of river hydromorphology to strengthen the ability of the model to predict alterations, especially of $\mathrm{pH}$, temperature and conductivity.

Acknowledgements. The authors gratefully thank Prof. Karen K. Serieyssol, Dr. François Straub and the anonymous reviewer for their valuable comments and help in improving the manuscript and Bruno Berthome for his help with GIS projects. The Adour-Garonne, Loire-Bretagne and RhôneMéditerranée Water Agencies are thanked for providing the chemical data.

\section{References}

AFNOR. 2003. NF EN 13946. Qualité de l'eau - Guide pour l'échantillonnage en routine et le prétraitement des diatomées benthiques de rivières. Paris: AFNOR.

AFNOR. 2004. Qualité de l'eau - Guide pour l'identification et le dénombrement des échantillons de diatomées benthiques de rivières, et leur interprétation. Paris: AFNOR.

AFNOR. 2007. NF T90-354 - Qualité de l'eau - détermination de l'indice Biologique Diatomées (IBD). Paris: AFNOR.

Allan JD. 2004. Landscapes and Riverscapes: the influence of land use on stream ecosystems. Annu Rev Ecol Evol Syst 35: 257-284.

Alric B, Jenny J-P., Berthon V, et al. 2013. Local forcings affect lake zooplankton vulnerability and response to climate warming. Ecology 94: 2767-2780.

APHA. 2012. Standard methods for examination of water and wastewater, 22nd ed. Washington DC: APHA.

Bader H-P, Baccini P. Monitoring and control of regional material fluxes. In: Schulin R, Desaules A,Webster R, Von Steiger B, eds. Soil monitoring: early detection and surveying of soil contamination and degradation. Basel: Birkhäuser Verlag, 1993, pp. 25-34.

Battarbee R, Jones V, Flower R, et al. Diatoms. In: Smol J, Birks HJ, Last W, Bradley R, Alverson K, eds. Tracking environmental change using lake sediments. Netherlands: Springer, 2001, pp. 155-202.

B-Béres V, Török P, Kókai Z, Krasznai ET, Tóthmérész B, Bácsi I. 2014. Ecological diatom guilds are useful but not sensitive enough as indicators of extremely changing water regimes. Hydrobiologia 738, 191-204.

Berthon V, Bouchez A, Rimet F. 2011. Using diatom life-forms and ecological guilds to assess organic pollution and trophic level in rivers: a case study of rivers in south-eastern France. Hydrobiologia 673: 259-271.

Berthon V, Alric B, Rimet F, Perga M-E. 2014. Sensitivity and responses of diatoms to climate warming in lakes heavily influenced by humans. Freshw Biol 59: 1755-1767.

Biggs B, Gerbeaux P. 1993. Periphyton development in relation to macroscale (geology) and micro-scale (velocity) limiters in two gravel-bed rivers, New-Zealand. N Z J Mar Freshwater Res 27: 39-53.

Cantonati M, Scola S, Angeli N, Guella G, Frassanito R. 2009. Environmental controls of epilithic diatom depth-distribution in an oligotrophic lake characterized by marked water-level fluctuations. Eur J Phycol 44: 15-29.

Cattaneo A, Kerimian T, Roberge M, Marty J. 1997. Periphyton distribution and abundance on substrata of different size along a gradient of stream trophy. Hydrobiologia 354: 101-110.

Cazaubon A, Rolland T, Loudiki M. 1995. Heterogeneity of periphyton in French Mediterranean rivers. Hydrobiologia 300-301: 105-114.

CEMAGREF. 1982. Étude des méthodes biologiques d'appréciation quantitatives de la qualité des eaux. Rapport Division Qualité des Eaux Lyon. Lyon: Agence de l'Eau Rhône-Méditerranée-Corse CEMAGREF.

CEN. 2003. EN 13946: 2003. Water quality: guidance standard for the routine sampling and pretreatment of benthic diatoms from rivers. Brussels: European Committee for Standardization.

Coste M, Boutry S, Tison-Rosebery J, Delmas F. 2009. Improvements of the biological diatom index (BDI): description and efficiency of the new version (BDI-2006). Ecol Indic 9: 621-650.

DeVito J, Meik JM, Gerson MM, Formanowicz Jr. 2004. Physiological tolerances of three sympatric riparian wolf spiders (Araneae: Lycosidae) correspond with microhabitat distributions. Can J Zool 82: 1119-1125.

Dionisio-Sese ML, Miyachi S. 1992. The effect of sodium chloride on carbonic anhydrase activity in marine microalgae. $J$ Phycol 28: 619-624.

Egge JK. 1998. Are diatoms poor competitors at low phosphate concentrations? J Mar Syst 16: 191-198.

Ellwood NTW, Whitton BA. 2007. Importance of organic phosphate hydrolyzed in stalks of the lotic diatom Didymosphenia geminata and the possible impact of atmospheric and climatic changes. Hydrobiologia 592: 121-133.

Eminson D, Moss B. 1980. The composition and ecology of periphyton communities in freshwaters: 1 the influence of host type and external environment on community composition. Br Phycol J 15: 429-446.

European Commission. 2003. Common implementation strategy for the Water Framework Directive (2000/60/EC), Guidance no. 3 Analysis of Pressures and Impacts. Office for Official Publications of the European Communities Luxembourg.

Falasco E, Piano E, Bona F. 2016. Suggestions for diatom-based monitoring in intermittent streams. Knowl Manag Aquat Ecosyst 417: 38 .

Fauth JE, Bernardo J, Camara M, Resetarits WJ, Van Buskirk J, McCollum SA. 1996. Simplifying the jargon of community ecology: a conceptual approach. Am Nat 147: 282-286.

Feminella JW, Hawkins CP. 1995. Interactions between stream herbivores and periphyton: a quantitative analysis of past experiments. J N Am Benthol Soc 14: 465-509.

Gottschalk S, Kahlert M. 2012. Shifts in taxonomical and guild composition of littoral diatom assemblages along environmental gradients. Hydrobiologia 694: 41-56. 
Hastie TJ, Tibshirani RJ. 1990. Generalized additive models. New York: Chapman \& Hall.

Hlúbiková D, Novais MH, Dohet A, Hoffmann L, Ector L. 2014. Effect of riparian vegetation on diatom assemblages in headwater streams under different land uses. Sci Total Environ 475: 234-247.

Hoagland KD, Roemer SC, Rosowski JR. 1982. Colonization and community structure of two periphyton assemblages, with emphasis on the diatoms (Bacillariophyceae). Am J Bot 69: 188-213.

Hofmann G, Werum M, Lange-Bertalot H. 2011. Diatomeen im Süsswasser-Benthos von Mitteleuropa: Bestimmungsflora Kieselalgen für die ökologische Praxis: über 700 der häufigsten Arten und ihre Ökologie, A.R.G. Gantner Verlag KG. Königstein, Germany: Distributed by Koeltz Scientific Books, Ruggell.

Jackson DA. 1993. Stopping rules in principal components analysis: a comparison of heuristical and statistical approaches. Ecology 74 2204-2214.

Johnson RE, Tuchman NC, Peterson CG. 1997. Changes in the vertical microdistribution of diatoms within a developing periphyton mat. J N Am Benthol Soc 16: 503-519.

Krammer K, Lange-Bertalot H. 1986. Bacillariophyceae 1. Teil: Naviculaceae. Heidelberg: Spektrum Akademischer Verlag.

Krammer K, Lange-Bertalot H. 1988. Bacillariophyceae 2. Teil: Bacillariaceae, Epithemiaceae, Surirellaceae. Heidelberg: Spektrum Akademischer Verlag.

Krammer K, Lange-Bertalot H. 1991a. Bacillariophyceae 3. Teil: Centrales, Fragilariaceae, Eunotiaceae. Heidelberg: Spektrum Akademischer Verlag.

Krammer K, Lange-Bertalot H. 1991b. Bacillariophyceae 4. Teil: Achnanthaceae. Kritische Ergänzungen zu Navicula (Lineolatae) und Gomphonema. Heidelberg: Spektrum Akademischer Verlag.

Lange-Bertalot H. 1979. Pollution tolerance of diatoms as a criterion for water quality estimation. Nova Hedwigia, Beih 64: 285-304.

Lange-Bertalot H. 1993. 85 New taxa and much more than 100 taxonomic clarifications supplementary to Süsswasserflora von Mitteleuropa. Berlin, Stuttgart: J. Cramer, 454 p.

Lange-Bertalot H. 2001. Diatoms of Europe: diatoms of the European inland waters and comparable habitats. Vol. 2, Navicula sensu stricto, 10 genera separated from Navicula sensu lato, Frustulia. Königstein, Germany: A.R.G. Gantner Verlag KG. Distributed by Koeltz Scientific Books, Ruggell.

Lange-Bertalot H, Krammer K. 2002. Diatoms of Europe: Diatoms of the European inland waters and comparable habitats. Vol. 3, Cymbella. Königstein, Germany: A.R.G. Gantner Verlag KG. Distributed by Koeltz Scientific Books, Ruggell.

Lange-Bertalot H, Krammer K. 2003. Diatoms of Europe: Diatoms of the European inland waters and comparable habitats. Vol. 4, Cymbopleura, Delicata, Navicymbula, Gomphocymbellopsis, Afrocymbella. Königstein, Germany: A.R.G. Gantner Verlag KG. 3: Distributed by Koeltz Scientific Books, Ruggell.

Lange K, Liess A, Piggott JJ, Townsend CR, Matthaei CD. 2011. Light, nutrients and grazing interact to determine stream diatom community composition and functional group structure: Diatom responses to light, nutrients and grazing. Freshw Biol 56: 264-278.

Lange K, Townsend CR, Matthaei CD. 2015. A trait-based framework for stream algal communities. Ecol Evol 6: 23.

Larras F, Bouchez A, Rimet F, Montuelle B. 2012. Using bioassays and species sensitivity distributions to assess herbicide toxicity towards benthic diatoms. PLOS ONE 7: e44458.

Larras F, Keck F, Montuelle B, Rimet F, Bouchez A. 2014. Linking diatom sensitivity to herbicides to phylogeny: a step forward for biomonitoring? Environ Sci Technol 48: 1921-1930.
Larson CA, Passy SI. 2012. Taxonomic and functional composition of the algal benthos exhibits similar successional trends in response to nutrient supply and current velocity. FEMS Microbiol Ecol 80: 352-362.

Legendre P, Gallagher E. 2001. Ecologically meaningful transformations for ordination of species data. Oecology 129: 271-280.

LEMA. 2006. LOI no. 2006-1772 du 30 décembre 2006 sur l'eau et les milieux aquatiques, Journal Officiel de la République Française 303.

Levkov Z. 2009. Diatoms of Europe: Diatoms of the European inland waters and comparable habitats. Vol. 5, Amphora sensu lato. Königstein, Germany: A.R.G. Gantner Verlag KG. Distributed by Koeltz Scientific Books, Ruggell.

Marcel R, Agnès B, Rimet F. 2013. Influence of herbicide contamination on diversity and ecological guilds of river diatoms. Cryptogamie, Algol 34: 169-183.

McCormick PV. Resource competition and species coexistence in freshwater benthic algal assemblages. In: Stevenson J, Bothwell M, Lowe R, eds. Algal Ecology: freshwater benthic ecosystems. London: Academic Press, 1996, pp. 155-202.

Morin S, Duong TT, Herlory O, Feurtet-Mazel A, Coste M. 2008. Cadmium toxicity and bioaccumulation in freshwater biofilms. Arch Environ Contam Toxicol 54: 173-186.

Oksanen J, Blanchet FG, Kindt R, et al. 2015. Package "vegan." Community ecology package version 2.2"1. Available at: https:// CRAN.R-project.org/package=vegan [Accessed: 14/02/2015].

Passy SI. 2007. Diatom ecological guilds display distinct and predictable behavior along nutrient and disturbance gradients in running waters. Aquat Bot 86: 171-178.

Passy SI, Larson CA. 2011. Succession in stream biofilms is an environmentally driven gradient of stress tolerance. Microb Ecol 62: 414-424.

Planas D. Acidification effects. In: Stevenson J, Bothwell M, Lowe R, eds. Algal Ecology: freshwater benthic ecosystems. London: Academic Press, 1996, pp. 497-530.

Poulíčková A, Hašler P, Lysáková M, Spears B. 2008. The ecology of freshwater epipelic algae: an update. Phycologia 47: 437-450.

Pound KL, Lawrence GB, Passy SI. 2013. Wetlands serve as natural sources for improvement of stream ecosystem health in regions affected by acid deposition. Glob Change Biol 19: 2720-2728.

Pringle CM. 1990. Nutrient spatial heterogeneity: effects on community structure, physiognomy, and diversity of stream algae. Ecology 71: 905-920.

R Development Core Team. 2013. R: A language and environment for statistical computing. Austria: R Foundation for Statistical Computing.

Reichardt E. 1999. Zur Revision der Gattung Gomphonema: Die Arten um G. affine/insigne, G. angustatum/micropus, G. acuminatum sowie gomphonemoide Diatomeen aus dem Oberoligozän in Böhmen. Königstein, Germany: A.R.G. Gantner Verlag KG. Distributed by Koeltz Scientific Books, Ruggell.

Reyjol Y, Spyratos V, Basilico L. 2013. Bioindication: des outils pour évaluer l'état écologique des milieux aquatiques - perspectives en vue du $2^{\mathrm{e}}$ cycle DCE-Eaux de surface continentales. Paris: ONEMA.

Rimet F. 2009. Benthic diatom assemblages and their correspondence with ecoregional classifications: case study of rivers in northeastern France. Hydrobiologia 636: 137-151.

Rimet F. 2012. Recent views on river pollution and diatoms. Hydrobiologia 683: 1-24.

Rimet F, Bouchez A. 2011. Use of diatom life-forms and ecological guilds to assess pesticide contamination in rivers: lotic mesocosm approaches. Ecol Indic 11: 489-499.

Rimet F, Bouchez A. 2012. Life-forms, cell-sizes and ecological guilds of diatoms in European rivers. Knowl Manag Aquat Ecosyst 406: 01 . 
Rimet F, Ector L, Cauchie H-M., Hoffmann L. 2009. Changes in diatom-dominated biofilms during simulated improvements in water quality: implications for diatom-based monitoring in rivers. Eur J Phycol 44: 567-577.

Round FE, Crawford RM, Mann DG. 1990. The diatoms: biology \& morphology of the genera. Cambridge/England, New York: Cambridge University Press, 747 p.

Sabater S. 2000. Diatom communities as indicators of environmental stress in the Guadiamar River, SW. Spain, following a major mine tailings spill. J Appl Phycol 12: 113-124.

Song X. 2007. Trends in benthic algal community response to a smallscale gradient of current velocities along a streambed transect. PhD thesis, College of Bowling Green State University, United States.

Steinman AD. Effects of grazers on freshwater benthic algae. In: Stevenson RJ, Bothwell ML, Lowe RJ, Thorp JH, eds. Algal Ecology. San Diego: Academic Press, 1996, pp. 341-373.

Steinman AD., McIntire, C.D. 1986. Effects of current velocity and light energy on the structure for periphyton assemblage in laboratory streams. J Phycol 22: 352-361.

Steinman AD, McIntire CD, Gregory SV, Lamberti GA. 1989. Effects of irradiance and grazing on lotic algal assemblages. J Phycol 25: $478-485$.

Stenger-Kovács C, Lengyel E, Crossetti LO, Üveges V, Padisák J. 2013. Diatom ecological guilds as indicators of temporally changing stressors and disturbances in the small Torna-stream, Hungary. Ecol Indic 24: 138-147.

Stevenson J. 2014. Ecological assessments with algae: a review and synthesis. J Phycol 50: 437-461.

Stevenson RJ, Peterson CG, Kirschtel DB, King CC, Tuchman NC. 1991. Density-dependent growth, ecological strategies, and effects of nutrients and shading on benthic diatom succession in streams. J Phycol 27: 59-69.

Tison J, Park YS, Coste M, et al. 2005. Typology of diatom communities and the influence of hydro-ecoregions: a study on the French hydrosystem scale. Water Res 39: 3177-3188.

Tison J, Park YS, Coste M, et al. 2007. Predicting diatom reference communities at the French hydrosystem scale: a first step towards the definition of the good ecological status. Ecol Model 203: 99-108.

Torrisi M, Rimet F, Cauchie H-M., Hoffmann L, Ector L. 2006. Bioindication par les diatomées épilithiques et épiphytes dans la rivière sÛre (luxembourg). Belg J Bot 139: 39-48.

Van Dam H, Mertens A, Sinkeldam J. 1994. A coded checklist and ecological indicator values of freshwater diatoms from The Netherlands. Netherland J Aquat Ecol 28: 117-133.

Videau C, Khalanski M, Penot M. 1980. Physiological response to chlorination of the unicellular marine alga Dunaliella primolecta Butcher. J Exp Mar Biol Ecol 47: 113-126.

Wasson JG, Chandesris A, Pella H, Blanc L. 2002. Les hydroécorégions de France métropolitaine. Approche régionale de la typologie des eaux courantes et éléments pour la définition des peuplements de référence d'invertébrés. Lyon: Ministère de l'Aménagement du Territoire et de l'Environnement, CEMAGREF, BEA/LHQ, pp. 1-190.

WFD. 2000. Directive 2000/60/EC of the European Parliament and of the Council of 23rd October 2000 establishing a framework for community action in the field of water policy, Official Journal of the European Communities: 22/12/2000.

Wood SN. 2008. Fast stable direct fitting and smoothness selection for generalized additive models. $J R$ Stat Soc Ser B Stat 70: 495-518.

Wood SN. 2011. Fast stable restricted maximum likelihood and marginal likelihood estimation of semiparametric generalized linear models. J R Stat Soc B 73: 3-36.

Wood S, Wood MS. 2015. Package "mgcv". R package version 1.7-29. Available at: https://cran.r-project.org/package $=\mathrm{mgcv}$ [Accessed: 14/02/2015].

Zarauz L, Irigoien X, Fernandes JA. 2008. Modelling the influence of abiotic and biotic factors on plankton distribution in the Bay of Biscay, during three consecutive years (2004-06). J Plankton Res 30: 857-872.

Zelinka M, Marvan P. 1961. Zur Prazisierung der biologischen Klassifikation der Reinheit fliessender Gewasser. Arch Hydrobiol 57: 389-407. 


\section{Appendix 1}

Plots of the diatoms metrics along the environmental gradients. The diatom metrics are relative abundances of the diatoms ecological guilds and life forms, in \%. Environmental gradients: total phosphorus (TP, in $\left.\mathrm{mg} \mathrm{L}^{-1}\right)$; conductivity $($ Cond, in $\left.\mu \mathrm{S} \mathrm{cm}{ }^{-1}\right)$; nitrate $\left(\mathrm{NO}_{3}{ }^{-}\right.$, in $\left.\mathrm{mg} \mathrm{L}^{-1}\right) ; \mathrm{pH}$.

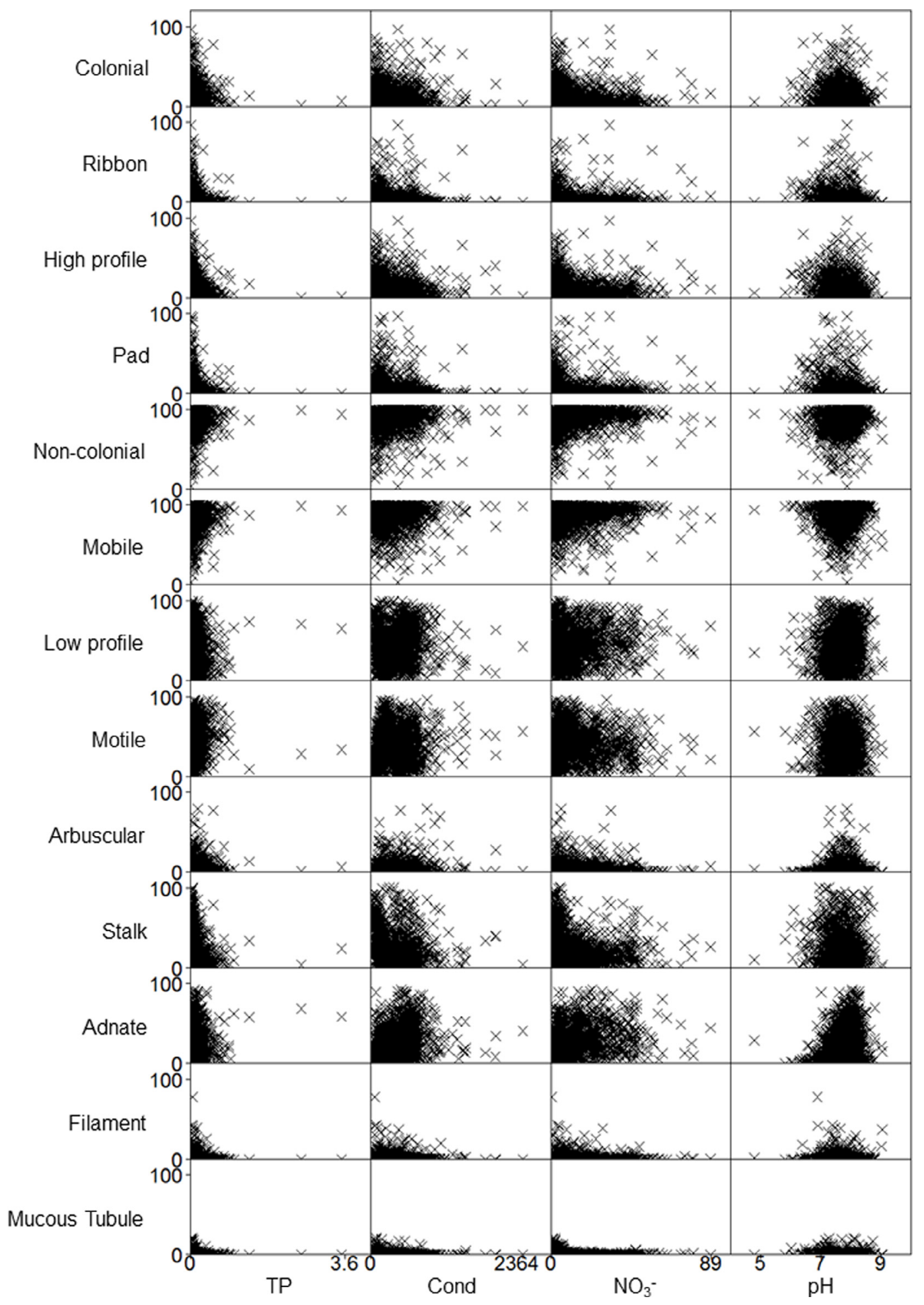




\section{Appendix 2}

Plots of the diatoms metrics along the environmental gradients. The diatom metrics are relative abundances of the diatoms ecological guilds and life forms, in $\%$. Environmental gradients: temperature $\left(\mathrm{T}\right.$, in $\left.{ }^{\circ} \mathrm{C}\right)$; dissolved oxygen $\left(\mathrm{DO}\right.$, in $\left.\mathrm{mg} \mathrm{L}^{-1}\right)$; dissolved organic carbon (DOC, in $\mathrm{mg} \mathrm{L}^{-1}$ ); five-day biological oxygen demand (BOD5, in $\mathrm{mg} \mathrm{L}^{-1}$ ).

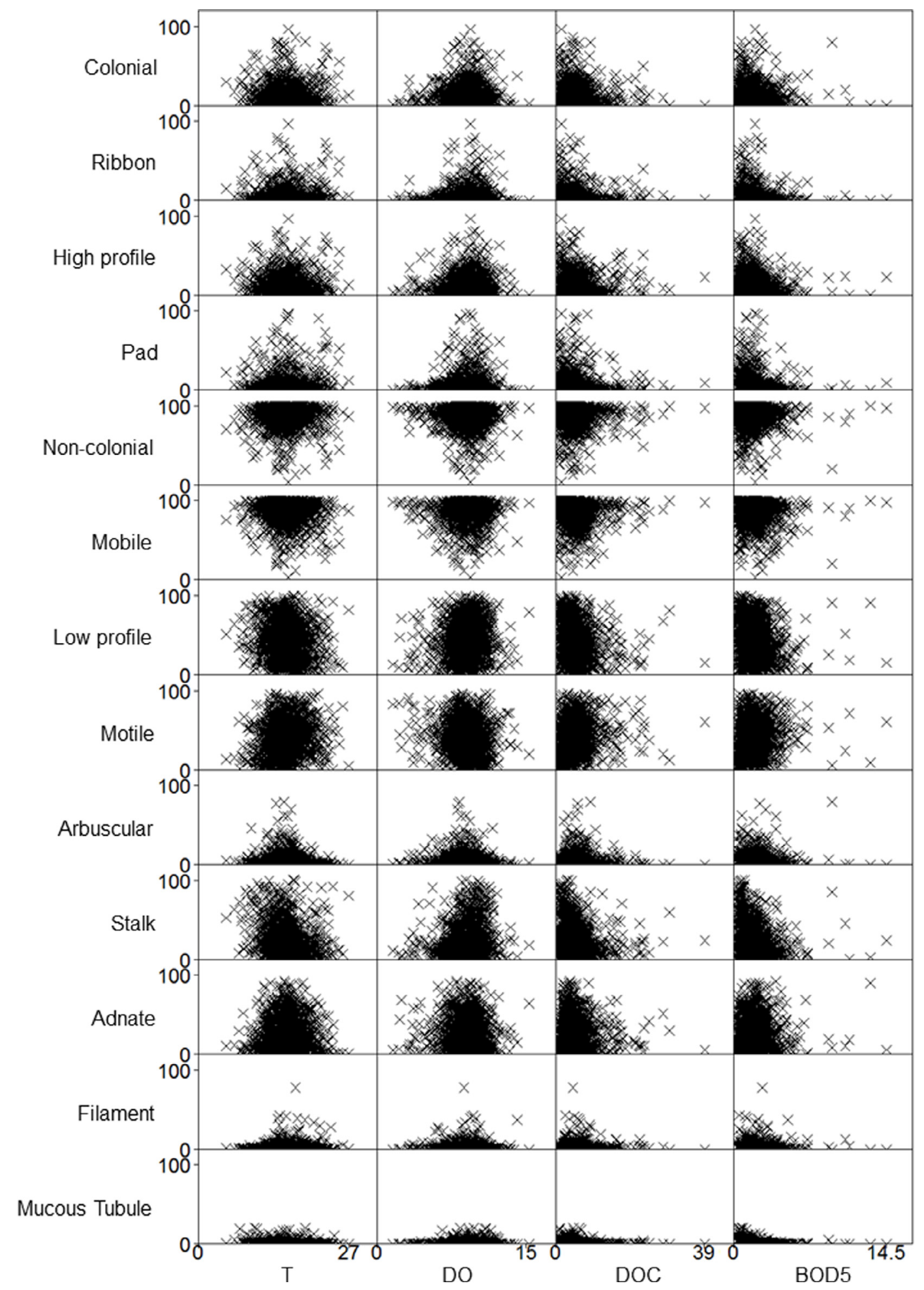

Cite this article as: Marcel R, Berthon V, Castets V, Rimet F, Thiers A, Labat F, Fontan B. 2017. Modelling diatom life forms and ecological guilds for river biomonitoring. Knowl. Manag. Aquat. Ecosyst., 418, 1. 